\title{
トピックス
}

\section{II. 病態}

\section{3. 自己抗体}

\section{村上 孝作 ${ }^{1)}$ 藤井 隆夫 ${ }^{2)}$ 三森 経世 $^{3)}$}

要旨

関節リウマチ（rheumatoid arthritis：RA）は種々の自己抗体の出現を特徽とする代表的な全身性自己免 疫疾患である. 自己抗体の中でリウマトイド因子 $(\mathrm{RF})$ と抗CCP抗体は, 関節リウマチの診断のみならず, 治療反応性や骨破壊進行を予測するための重要な血清学的マーカーである。しかし，抗体価と疾患活動性 との相関については両者で異なる可能性があり, 臨床的意義の異同について概説する.

〔日内会誌 $101 ： 2844 \sim 2850,2012 〕$

Key words リウマトイド因子, 抗CCP抗体, 抗体価

\section{はじめに}

関節リウマチ（rheumatoid arthritis：RA）は 骨軟骨を破壞する慢性多発性関節炎を特徵とす る炎症性疾患であるが，また代表的な自己免疫 疾患でもある。すなわち, 何らかの理由で自己 免疫寛容の破綻が生じ, その結果として自己抗 体が産生される。

RAでは 70 年以上前にリウマトイド因子 (rheumatoid factor : RF) が発見され, 近年までRA において臨床的に利用される唯一の自己抗体で あった. しかし, RFは他疾患でも検出されるた め, RAの早期診断に役立つ特異的自己抗体の発 見が望まれ,種々の新たなRA関連抗体が報告さ
れた (表 1) ${ }^{1)}$.これらの対応抗原は軟骨の基質や ストレス蛋白, 各種酵素など様々であり, 更に, 個々の症例でも検出される自己抗体の種類に統 一性は無い. また, シトルリン化されることに よって初めて抗原性を獲得するものがある.従っ て, 関節リウマチの自己免疫応答は単一の抗原 に対するものではないことが示唆される.

これらの中で, 現時点で臨床的に有用とされ ているのはリウマトイド因子と抗環状シトルリ ン化ペプチド抗体 (Anti-cyclic citrullinated peptide antibody : 抗CCP抗体) である. 2007 年よ り抗CCP抗体の測定が本邦で保険収載されてか ら, RAの診断における血清学的マーカーの重要 性が再認識されている.

本稿では, RAの診断において重要な自己抗体

\footnotetext{
1) 大阪赤十字病院リウマチ膠原病内科, 2) 京都大学附属病院リウマチセンター, 3) 同 免疫・膠原病内科

Rheumatoid Arthritis : Progress in Diagnosis and Treatment. Topics : II. Pathophysiology ; 3. Autoantibodies in rheumatoid arthritis.

Kosaku Murakamii ${ }^{1}$, Takao Fujii ${ }^{2}$ and Tsuneyo Mimori3) $:{ }^{1)}$ Department of Clinical Immunology and Rheumatology, Osaka Red Cross Hospital, Japan, 2) Department of the Control for Rheumatic Diseases, Kyoto University Hospital, Japan and 3) Department of Rheumatology and Clinical Immunology, Kyoto University Hospital, Japan.
} 
表 1. 関節リウマチにおける自己抗体の対応抗原（文献 1 より，一部改変）

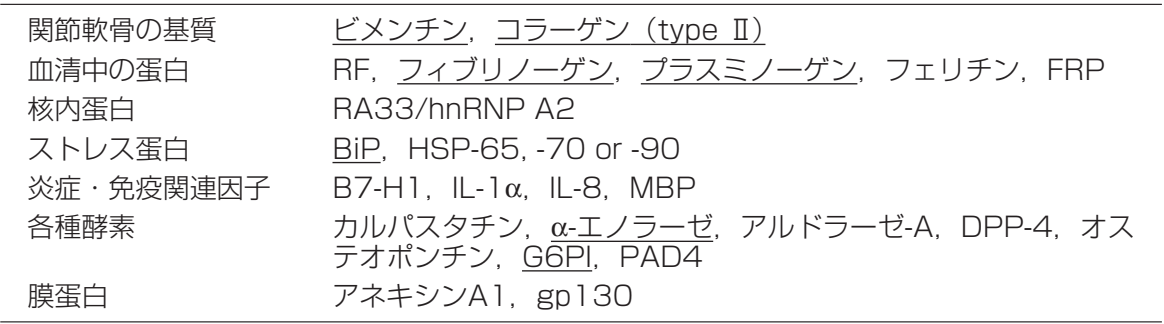

下線：シトルリン化蛋白抗原としても同定されているもの

RF : rheumatoid factor, FRP : follistatin related protein, BiP : immunoglobulin binding protein, HSP : heat shock protein, IL : interleukin, MBP : Myelin basic protein, DPP-4 : dipeptidyl peptidase-4, G6PI : glucose-6-phosphate isomerase, PAD4 : peptidylarginine deiminase type 4, gp 130 : Glycoprotein 130

であるRFと抗CCP抗体の意義を中心に解説する.

\section{1.リウマトイド因子}

RFはIgGのFc部分と反応する自己抗体であり， ラテックス凝集法 (RAテスト) や血球凝集反応 (RAHA), 免疫比濁法などのRF定量法で測定さ れる. RF定量法のカットオフ值はこれまで測定 法や施設間での統一がなされていなかったが,

「健常人での陽性率が $5 \%$ となる值をカットオフ 值 $15 \mathrm{IU} / \mathrm{ml}$ とする」ことで標準化することが提 唱され, 2011 年 8 月より日本リウマチ学会にお いて認証された.

RFはRA全体の約 70\% で検出されるが, 早期 関節リウマチでは陽性率は $50 \%$ 以下に低下する. また, RFは健常人でも数\%程度で陽性を示し， 特に高齢者では陽性率が増加する. RA以外の膠 原病 (特にSjögren症候群, 全身性エリテマトー デス, 強皮症, 混合性結合組織病）や慢性肝炎 (ウイルス性肝炎) - 肝硬変, 慢性感染症 (感染 性心内膜炎や結核）など多数の疾患で陽性とな るため, 疾患特異性は必ずしも高くない(表 2). またRFの力価がRAの活動性と相関する症例は必 ずしも多くないため, 一部の症例をのぞいて頻 回に測定する必要はない.

\section{2. 抗ガラクトース欠損IgG抗体}

RA患者血清中のIgGは, 健常者のIgGと比較し 糖鎖末端のガラクトースの久損が高頻度である ことが明らかとなり,この糖鎖異常がRAの発症 やRFの産生に関与する可能性が示唆された。 そ

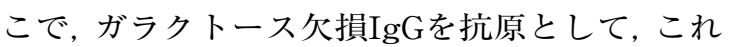
に結合する抗体の測定法が開発されている。本 抗体は従来のRFよりもRAにおける感度が高く, 早期RAやRF陰性患者での陽性率も高い. しかし 特異度も低下するため, 現在はRF陰性時の補助 的なマーカーとして使用されることが多い.

\section{IgG型リウマトイド因子（IgG-RF）}

通常の方法(凝集反応)で測定されるRFはIgM 型のみ（IgM-RF）であるが, IgG型RFを測定す る方法が開発されている. IgG-RFはIgM-RFに比 LRAでの陽性率は 20〜30\% と低いものの特異 度は高い. IgM-RFが陰性であればIgG-RFはほと んどのすべての症例で陰性であり測定する意義 がない。ただし，関節液中ではIgG-RFの陽性率 は高いとされている。なお両者が陽性の場合に はIgM-RFより IgG-RFのほうがより疾患活動性 


\section{トピックス}

表 2. RFが陽性となり得る疾患

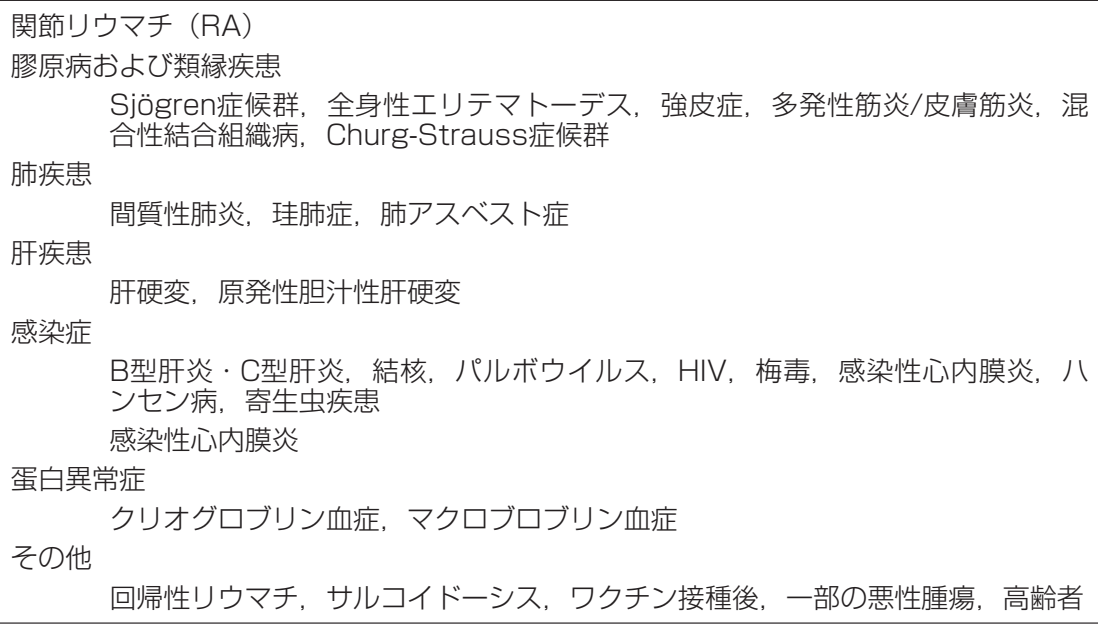

と並行しやすい.

IgG-RFは, 高度の関節炎のみでなくRAに認め られる血管炎や間質性肺炎などの関節外症状と 相関すると考えられている。

\section{4. 抗CCP抗体}

抗CCP抗体は, RAの対応抗原として同定され たシトルリン化フィラグリンの主要抗原エピトー プペプチドを人工的に環状化させた分子 $(\mathrm{CCP})$ に対する自己抗体である ${ }^{2)}$. その後, ランダムぺ プチドライブラリーから反応性の高い複数個の ペプチド(アミノ酸配列は公開されていない)を 選択して抗原とした第 2 世代のキットが開発さ れ，世界中で広く利用されている。他にも種々 の抗シトルリン化蛋白がRAの自己抗原として知 られているが (表 1 ), 現時点において本邦で保 険収載されている抗シトルリン化蛋白抗体(Anticitrullinated protein antibody : ACPA)は抗CCP 抗体のみである.

抗CCP抗体はRAにおける血清マーカーの中で 最も特異度が高く, RA診断における有用性が確 立している。これまでの報告を集積したメタア
ナリシスによれば3)，抗CCP抗体について，29 報告・11,821 症例で感度 $67 \%$ (95\% 信頼区間： 65～68)，特異度 95\%（95\% 信頼区間：95～98） であり, RFと比較した場合, 感度は同等かやや 高く，特異度は非常に高いことが確認された。

また, 陽性尤度比 (RA症例の中で検查結果が陽 性となる割合) が 12.77 , 陰性尤度比 (非RA症例 の中で検査結果が陽性となる割合）が 0.32 であ り，RAは非RAよりも抗CCP抗体が陽性となる 頻度が特に高いことが確認された。

また，抗CCP抗体を始めとするACPAはRA 高感受性のHLA shared epitope と相関し, 抗体陽 性患者においては喫煙により疾患活動性が増悪 することが報告されている.

2007 年に報告されたPROMPT試験)では，抗 CCP抗体陽性の診断未確定関節炎患者にメト卜 レキサート（MTX）を投与した場合， 1 年後に RAと診断確定される割合が約 $20 \%$ と，プラセ ボ群の $90 \%$ と比較し有意に低かったが（ $p=$ 0.0002), 抗CCP抗体陰性例では両群間で差が認 められず， 3 年後の診断確定率はいずれも $40 \%$ 程度であった. X線所見の進行についても同様で, 抗CCP抗体陽性例ではMTX投与によって進行が 
遅れたが，陰性例では有意差がなかった，以上 の成績から, 抗CCP抗体陽性のUA患者における MTX療法は, RAと確定診断される患者数を有意 に減らし, 関節破壊の進行を有意に遅らせるが, 抗CCP抗体陰性例ではその意義は少ないものと 考えられる.

\section{5. 新RA分類基準におけるRFと抗CCP 抗体の意義}

2010 年にACR (米国リウマチ学会) とEULAR (欧州リウマチ学会)の共同作成による新たなRA の分類基準 (以下, 新基準) が上梓された ${ }^{5}$. 新 基準では，他疾患では説明のつかない，少なく とも 1 カ所以上の関節腫脹を認める患者を対象 として, 関節症状の分布と数, 血清学的因子, 炎症反応の有無, 滑膜炎の持続期間の 4 項目か らスコアを算出し, 10 点満点中 6 点以上であれ ばRAと分類する. その中でも特に血清学的因子 （RFもしくはACPA）では基準值上限より 3 倍以 下であれば低力価として 2 点, 3 倍を超えれば高 力価として 3 点と, 他の項目と比較しても高い 配点となっている。

従って, 例えばRFとACPAが共に㓌性であれ ば他項目が満点でなければならず，その有無が 診断に大きく関わっている。しかし一方で, 特 異度の異なるRFとACPAとを同等とみなす点に ついて批判もある.

最近, 新基準におけるRF抗体価の意義につい ての検証が報告された ${ }^{6)}$. ライデン大学, ベルリ ン，ノルウェーの 3 施設において未分化関節炎 (Undifferentiated arthritis：UA)を選択し, RF 抗体価と 1987 年改訂RA分類基準によるRA診断 との関連について検討された。例えばベルリン のコホート $(\mathrm{n}=154, \mathrm{RF}$ 基準值 : $24 \mathrm{U} / \mathrm{ml}$ 以下 $)$ では, RFのcut off值を $24 \mathrm{U} / \mathrm{ml}$ かその 3 倍で ある $72 \mathrm{U} / \mathrm{ml}$ (新基準における高力価相当)に引 き上げた場合, 陽性尤度比は 68.4 から 79.1 と上
昇したが, 同コホートでACPA除性/陽性をRA との判断基準にした場合の陽性尤度比は 93.2 と比較的高い傾向にあった. また, ACPA陰性患 者における高力価RFの陽性尤度比は 46.7 であっ たのに対し，RFが高力価でない患者における ACPA陽性の場合は 87.5 と 2 倍近くに上昇した. すなわち早期関節炎を予測する指標として, RF のcut off值を変更してもACPA陰性/陽性には及 ばないことが示唆された。一方, 同報告ではラ イデン大学のコホートにおいて, 骨破壊進行は 高力価RFで予測したほうがACPA陽性よりも将 来の関節破壊を良く予測することを付け加えて いる.もちろん高力価RF患者のほとんどはACPA 陽性と考えられることから解釈に注意は必要で あるが, 両抗体の特徴を比較する上で興味深い.

\section{6. 抗CCP抗体とRAの臨床経過との相関}

抗CCP抗体価とRAの臨床活動性との関連を示 した報告は少ない，筆者らは，発症 1 年以内に 受診し, 2 年以上外来に通院したRA患者 98 例に ついて初診時の RF と抗CCP抗体価がその後の臨 床経過や骨破壊に影響を及ぼすかどうかを検討 した.このコホートでは, 抗CCP抗体が基準值 を超えるが 3 倍以下であった患者がきわめて少 なかったため, 陰性群 $(\mathrm{RF}<11.7 \mathrm{IU} / \mathrm{ml}$, 抗CCP 抗体 $<4.5 \mathrm{U} / \mathrm{ml}$ ), 低力価陽性群 (RF 11.7 100, 抗CCP抗体 4.5 100), 高力価陽性群 (ともに 100 以上）に分類した。

図 1 に示すように, RF・抗CCP抗体いずれに おいてもどちらかが高力価であった場合には初 診から 2 年後のDAS28 の平均值が㓌性群と比較 して有意に高く, 臨床的寛解に至らない割合が 高かった。

また, 手部についてLarsen scoreによる骨破壊 の進行度 (Yearly Progression score : YP-score) を各患者群で比較したところ，図 2 で示すよう に抗CCP抗体は力価によらず陽性例で骨破壊の 


\section{トピックス}

RF

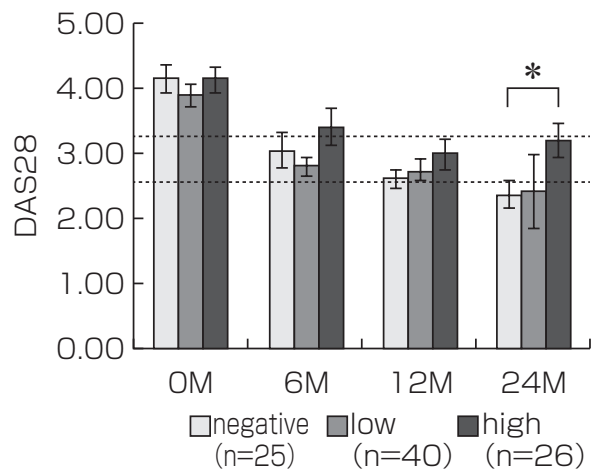

抗CCP抗体

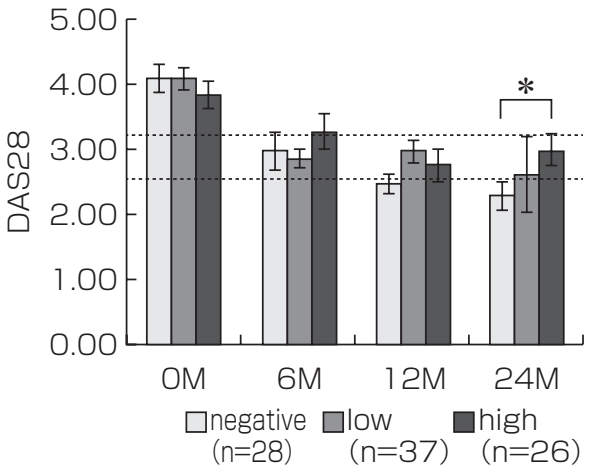

$* p<0.05$

図 1. 初診時のRFと抗CCP抗体により分類されたRA患者のDAS28 の推移

対象を初診時のRF（左）もしくは抗CCP抗体（右）で分類し, DAS28の推移を検討した. negative : 抗体陰性, low : 低力価陽性, high : 高力価陽性. 各々のcut off值は本文中に記載.
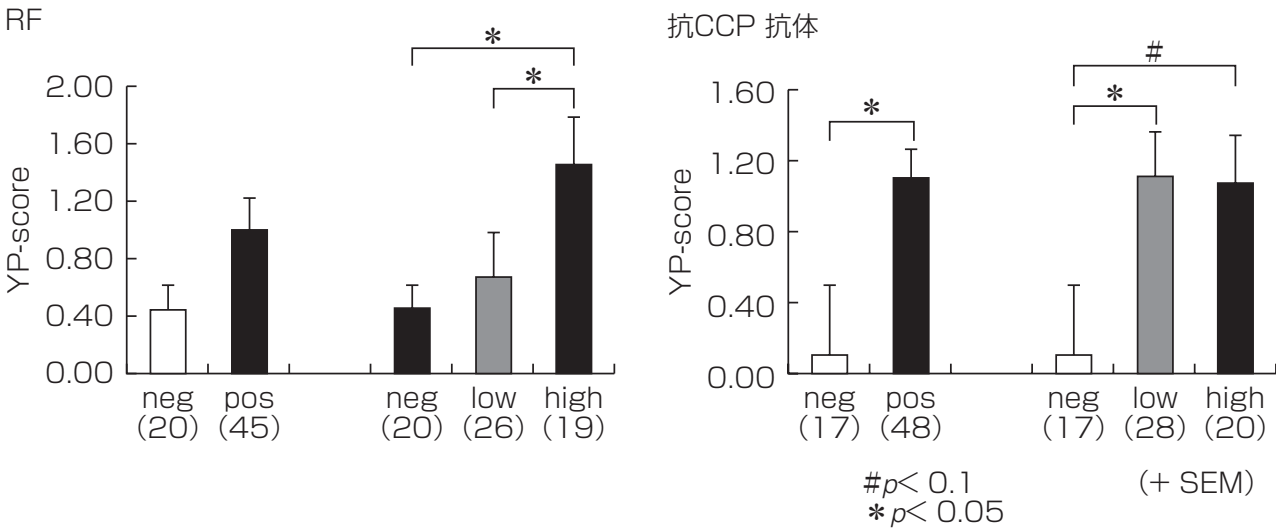

図 2. 初診時のRFと抗CCP抗体により分類されたRA患者の骨破壊

対象を初診時のRF（左）もしくは抗CCP抗体（右）で分類し，骨破壊の年間進行度を手部の Larsen score (Yearly progression : YP-score) を用いて検討した. neg : 抗体陰性, low：低力価陽性, high：高力価陽性. 各々のcut off値は本文中に記載.

進行が明らかであったのに対し, RFでは高力価 症例に限り他群と比較して有意な進行が示され た。したがって，RF高力価が関節破壊の強いリ スクであり, RF低力価の症例では骨破壊が緩徐 である可能性が示唆された.

なお，初診時から 2 年後までで使用されてい たRA治療薬については, 抗体陰性群ではNSAIDs (非ステロイド性抗リウマチ薬)のみで経過観察
されていた症例や,オーラノフィンやアクタリッ 卜など効果が比較的弱い抗リウマチ薬が使用さ れている症例の割合が高かった。一方，抗体高 值陽性群は，メトトレキサート（MTX）単独あ るいはMTXと他の抗りウマチ薬との併用率が低 值陽性群よりも高い傾向にあった.

以上の検討から，早期RAの診断時において， RFのみが低力価陽性であった場合と抗CCP抗体 
のみが低力価陽性であった場合とではその後の 臨床経過が異なる可能性が示唆される.

\section{7. その他の自己抗体}

表 1 に示したRAの自己抗体の中で, RF, 抗CCP 抗体以外にもいくつかの自己抗体について, そ の病因的意義, 臨床的意義が報告されている.

\section{1）抗カルパスタチン抗体}

カルパスタチン (calpastatin) はカルシウム依 存性システインプロテアーゼの一つであるカル パイン（calpain）の内在性阻害分子である。 カ ルパインは軟骨破壊をきたすシステインプロテ アーゼと考えられており, RAの病態にカルパイ ンが関与する可能性を示す多くの報告がある. カルパスタチンに対する自己抗体は 1995 年に 2 つのグループから独立して報告された ${ }^{7}$. 抗カル パスタチン抗体の陽性率はRA 57\% であったが, 他の膠原病でも陽性例が認められた。患者血清 中のIgGはカルパスタチンのカルパイン阻害作用 を抑制し，病態形成に関与する可能性が示唆さ れた。

2）抗ホリスタチン関連蛋白（FRP）抗体 RA患者滑膜cDNAライブラリーよりRA患者 血清中のIgGが認識する抗原がクローニングされ， ホリスタチン関連蛋白（follistatin-related protein：FRP)が同定された.FRPは滑膜で高発現 しており, RA患者血清中の $30 \%$, 滑液中の $44 \%$ に抗FRP抗体が認められた ${ }^{8}$. 抗FRP陽性患者は 陰性患者と比較しCRPと赤沈が有意に高く, 抗 リウマチ薬の治療強化が必要となる例が多かっ たことから，FRPに対する自己免疫応答がRA の病態を修飾している可能性が示唆された.

3）抗ミエリン塩基性蛋白（MBP）抗体

日本人に㧍ける 990 人のRA患者と 1,236 人の 健常人DNAを対象として, 一塩基多型 (SNP)を 用いた全ゲノム関連解析により，ミエリン塩基 性蛋白 (myelin basic protein：MBP) がRAの疾
患感受性遺伝子であることが見出された ${ }^{9)}$.さら に, MBP蛋白の発現上昇にリスクアレルが関連 していること, RA滑膜にはMBP蛋白が発現して いること, RA患者血清中に抗MBP抗体が高頻度 に検出されシトルリン化MBPを主に認識するこ とが明らかにされている。

4) 抗glucose-6-phosphate isomerase (GPI) 抗体

関節炎を自然発症する $\mathrm{K} / \mathrm{BxN}$ マウスの解析に より, 解糖系酵素である glucose-6-phosphate isomerase（GPI）に対する自己抗体産生が関節 炎発症の機序であることが明らかにされた，抗 GPI抗体は単独で関節炎を発症させることから， 病原性自己抗体であることが示唆される。ヒト RA患者においては抗GPI抗体が約 15\% に検出さ れ，陽性患者では関節炎の病勢を反映すること， 関節外症状を伴う重度のRAに陽性者が多いこと が報告されている10).

\section{おわりに}

抗CCP抗体とRFはいずれもRAの診断マー カーとして利用されるが, 診断特異度や関節破 壊予測因子としては抗CCP抗体の有用性が上回 る.一方, RF力価は (抗CCP抗体とは異なり) RA の治療反応性と並行し, その高力価が予後や治 療反応性を予測するマーカーと考えられる. RA 新分類基準では, 両抗体ともに正常上限の 3 倍 を低力価一高力価のcut off line と定めているが, その妥当性について引き続き評価が必要と思わ れる。

著者のCOI (conflicts of interest) 開示 : 本論文発表内容に 関連して特に申告なし

\section{文献}

1) Mewar D, et al : Autoantibodies in rheumatoid arthritis: a review. Biomed Pharmacother 60 : 648-655, 2006.

2）三森経世：【膠原病 診断と治療の進歩】新しい検査の 
意義と使い方 抗CCP抗体. 日内会誌 $96: 2132-2137$, 2007.

3) Nishimura K, et al : Meta-analysis : diagnostic accuracy of anti-cyclic citrullinated peptide antibody and rheumatoid factor for rheumatoid arthritis. Ann Intern Med 146: 797-808, 2007.

4) van Dongen $\mathrm{H}$, et al: Efficacy of methotrexate treatment in patients with probable rheumatoid arthritis : a doubleblind, randomized, placebo-controlled trial. Arthritis Rheum 56: 1424-1432, 2007.

5) Aletaha $\mathrm{D}$, et al : 2010 Rheumatoid arthritis classification criteria : an American College of Rheumatology/European League Against Rheumatism collaborative initiative. Arthritis Rheum 62 : 2569-2581, 2010.

6) van der Linden MP, et al : Toward a data-driven evaluation of the 2010 American College of Rheumatology/ European League Against Rheumatism criteria for rheumatoid arthritisis it sensible to look at levels of rheu- matoid factor? Arthritis Rheum 63 : 1190-1199, 2011.

7) Mimori T, et al : Autoantibodies to calpastatin (an endogenous inhibitor for calcium-dependent neutral protease, calpain) in systemic rheumatic diseases. Proc Natl Acad Sci U S A 92 : 7267-7271, 1995.

8) Tanaka $M$, et al:Potential preventive effects of follistatin-related protein/TSC-36 on joint destruction and antagonistic modulation of its autoantibodies in rheumatoid arthritis. Int Immunol 15 : 71-77, 2003.

9) Terao C, et al: Myelin basic protein as a novel genetic risk factor in rheumatoid arthritis - a genome-wide study combined with immunological analyses. PLoS One 6: e20457, 2011 .

10）松本 功：【総説】関節リウマチにおける自己抗体の産 生機序と病因性. 日本免疫学会雑誌 $28: 365-371,2005$. 